\title{
PENJADWALAN PRODUKSI DENGAN ALGORITMA HEURISTIK POUR (STUDI KASUS: KONVEKSI ONE WAY - MALANG)
}

\author{
ANDRI SULAKSMI, ANNISA KESY GARSIDE*, DAN FITHRIANY HADZIQAH \\ Jurusan Teknik Industri, Fakultas Teknik, Universitas Muhammadiyah Malang \\ Jl. Raya Tlogomas 246, Malang, Jawa Timur 65144 \\ Email: sulaksmiandri@gmail.com, anisa_garside@yahoo.com, fitriany17@yahoo.com
}

\begin{abstract}
ABSTRAK
Konveksi One Way memproduksi berbagai jenis kaos berdasarkan order yang datang dari konsumen. Dalam memenuhi order tersebut, perusahaan menggunakan aturan First Come First Serve dalam menjadwalkan urutan pengerjaan ordernya. Aturan ini sering tidak menguntungkan bagi order yang membutuhkan waktu proses yang pendek karena apabila order tersebut berada di belakang antrian maka harus menunggu yang lama sebelum diproses dan menyebabkan waktu penyelesaian seluruh order menjadi lebih panjang. Penelitian ini bertujuan untuk menjadwalkan urutan pengerjaan kaos di konveksi One Way dengan menggunakan algoritma heuristik Pour sehingga waktu penyelesaian menjadi lebih singkat dan order kaos bisa selesai tepat waktu. Tahapan-tahapan penelitian terdiri dari pengumpulan data, perhitungan waktu standar, perhitungan total waktu proses berdasarkan order, penjadwalan dengan metode awal perusahaan, penjadwalan dengan metode heuristik pour, dan perbandingan makespan antara kedua metode. Berdasarkan hasil penjadwalan menggunakan heuristik Pour diperoleh penghematan makespan sebesar 8,09 jam atau 19,25\% dibanding makespan dengan metode perusahaan saat ini.
\end{abstract}

Kata kunci: penjadwalan produksi, first come first serve, heuristik pour, makespan

\begin{abstract}
"One Way Convection" is a garment company which produces many kinds of t-shirt based on the customer's order. In order to fulfill the order, the company applies role of First-Come First-Serve for scheduling the order production sequence. This role is often disadvantageous for the order with short process time because if it is dispatched after the order with long process time, then it will take longer in queue and causes the completion time of all order to be longer. This research aims to schedule t-shirt's sequence operation in "One Way Convection" company by using Pour heuristic algorithm so that completion time becomes shorter and order fulfillment can be accomplished on-time. The steps in this methodology consist of collecting data, calculating standard time and total process time according to the order, scheduling using initial method proposed by company, scheduling using Pour heuristic algorithm, and comparing makespan of both approaches. According to the Pour Heuristic method, saving is obtained in makespan as 8.09 hours or $19.25 \%$ compared with initial method proposed by company.
\end{abstract}

Key words: production scheduling, first come first serve, pour heuristic, makespan

\section{PENDAHULUAN}

Salah satu masalah yang cukup penting dalam sistem produksi adalah bagaimana melakukan penjadwalan pembuatan produk (pekerjaan), agar pesanan dapat selesai sesuai dengan kontrak dan sumber-sumber daya yang tersedia dapat dimanfaatkan seoptimal mungkin. Masalah penjadwalan seringkali muncul jika terdapat $n$ pekerjaan yang akan diproses pada $m$ mesin, yang harus ditetapkan mana yang harus dikerjakan lebih dahulu dan pengalokasian operasi pada mesin sehingga diperoleh suatu

* Penulis korespondensi 
proses produksi yang terjadwal. Menurut Ginting (2009), penjadwalan adalah pengurutan pembuatan atau pengerjaan produk secara menyeluruh yang dikerjakan pada beberapa buah mesin. Tujuan dengan penjadwalan adalah meningkatkan penggunaan sumber daya, mengurangi persediaan barang setengah jadi atau sejumlah pekerjaan yang menunggu dalam antrian, dan mengurangi keterlambatan pada pekerjaan yang mempunyai batas waktu penyelesaian.

Perusahaan konveksi One Way merupakan perusahaan yang memproduksi berbagai macam kaos berdasarkan order yang datang dari konsumen. Dengan permintaan yang bersifat make to order, konveksi One Way menyadari pentingnya ketepatan waktu penyelesaian order dalam mempertahankan konsumen. Saat ini perusahaan melakukan penjadwalan pengerjaan kaos dengan aturan First Come First Serve (FCFS), di mana order yang datang terlebih dahulu akan dikerjakan terlebih dahulu. Apabila ada order kaos yang datang bersamaan, order akan dikerjakan melalui sistem antrian. Aturan ini sering tidak menguntungkan bagi order yang membutuhkan waktu proses yang pendek karena apabila order tersebut berada di belakang antrian maka harus menunggu yang lama sebelum diproses dan menyebabkan waktu penyelesaian seluruh order menjadi lebih panjang.

Proses pembuatan kaos pada konveksi One Way mengikuti tahapan proses yang sama meskipun desain kaos bisa berbeda sesuai dengan order yang datang, sehingga penjadwalan yang dihadapi termasuk dalam kategori penjadwalan flow shop. Penjadwalan flow shop akan menjadwalkan proses produksi dari masingmasing $n$ job yang mempunyai urutan proses produksi dan melalui $m$ mesin yang sama (Baker and Trietsch, 2009). Sudah banyak penelitian yang dilakukan untuk mencari penyelesaian penjadwalan dengan tujuan meminimumkan waktu penyelesaian job (makespan) diantaranya algoritma Campbell Dudek and Smith (CDS), Dannenbring, Nawaz, Enscore and Ham (NEH) dan heuristik Pour. Hasil penelitian oleh Soetanto dan Palit (2004) menunjukkan algoritma heuristik Pour memberikan performance yang cukup baik dalam menyelesaikan permasalahan penjadwalan flowshop dengan tujuan meminimalkan makespan jika dibandingkan dengan salah satu metode optimasi Mixed Integer Programming (MIP). Penelitian lain yang dilakukan oleh Siregar (2009) menunjukkan algoritma heuristik Pour mampu memberikan makespan lebih cepat 5,09\% dibanding aturan FCFS dalam penjadwalan yang dilakukan PT Cakra Compact Alumunium Industries Medan. Berdasarkan kelebihan yang ditunjukkan algoritma heuristik Pour dari beberapa penelitian terdahulu, maka penelitian ini bertujuan menjadwalkan urutan pengerjaan kaos di konveksi One Way dengan menggunakan algoritma heuristik Pour sehingga waktu penyelesaian menjadi lebih singkat dan order kaos bisa selesai tepat waktu.

\section{METODE}

Tahapan-tahapan yang dilakukan meliputi:

\section{Pengumpulan Data}

Data-data yang dibutuhkan untuk melakukan urutan pengerjaan order kaos adalah:

- Order kaos yang diterima konveksi One Way dan jumlahnya.

- Proses produksi untuk membuat kaos.

- Nama dan jumlah mesin.

- Waktu proses produksi tiap kaos pada tiap mesin.

- Kelonggaran dan rating faktor pada tiap mesin.

\section{Perhitungan Waktu Standar (Waktu Baku)}

Perhitungan waktu standar didasarkan dari data waktu proses produksi, kelonggaran, dan rating faktor yang diperoleh dari hasil pengamatan. Waktu standar adalah waktu yang dibutuhkan mesin yang berkerja secara normal untuk membuat sebuah kaos. Rumus untuk menghitung waktu standar yaitu: 
Waktu Normal $\left(\mathrm{W}_{\mathrm{n}}\right)=$

rata-rata waktu pengamatan $\times \frac{\text { rating factor } \%}{100 \%}$

Waktu Standar $=$

$\mathrm{W}_{\mathrm{s}}=\mathrm{W}_{\mathrm{n}} \times \frac{100 \%}{100 \%-\% \text { Allowance }}$

\section{Perhitungan Total Waktu Proses berdasarkan Order}

Total waktu proses merupakan waktu yang dibutuhkan untuk menyelesaikan suatu order berdasarkan jumlah permintaan yang diterima. Waktu ini dipengaruhi juga oleh jumlah mesin yang dimiliki oleh konveksi One Way, kapasitas produksi/mesin dan waktu standar untuk membuat sebuah kaos. Rumus untuk menghitung total waktu proses tiap order pada masing-masing mesin adalah :

Total waktu proses $=$

Waktu standar $\times$ jumlah permintaan/order

jumlah mesin $\times$ kapasitas produksi/mesin

\section{Penjadwalan dengan Metode Awal Perusahaan}

Pada tahap ini dilakukan penjadwalan awal sesuai dengan metode perusahaan yaitu menggunakan aturan FCFS.

\section{Penjadwalan dengan Metode Heuristik Pour}

Pada tahap ini dilakukan penjadwalan dengan algoritma heuristik Pour. Algoritma penjadwalan ini bertujuan untuk meminimalkan makespan (flowtime maksimum) berdasarkan pendekatan kombinasi. Hal ini dilakukan dengan cara mengganti setiap order dengan order lainnya dalam urutan sampai ditemukan urutan yang dapat memenuhi kriteria tujuan. Langkahlangkah pengerjaan algoritma heuristik Pour adalah (Pour, 2001):

1. Memilih job secara acak sebagai urutan pertama sementara dalam urutan pengerjaan.

2. Menempatkan job-job lain (selain job yang sudah dipilih sebagai urutan pertama) pada urutan berikutnya.

3. Memilih waktu proses terkecil untuk masingmasing mesin.

4. Melakukan penambahan waktu proses (completion time) pada setiap $\mathrm{P}_{\mathrm{ij}}$ dengan aturan increasing processing time, yaitu dengan menambahkan waktu proses secara kumulatif dari yang terkecil menuju yang terbesar pada setiap $\mathrm{P}_{\mathrm{ij}}$. Di mana $\mathrm{P}_{\mathrm{ij}}$ adalah waktu proses dari job ke-i pada mesin ke-j.

5. Menghitung sum of completion time $\left(\sum \mathrm{C}_{\mathrm{i}}\right)$ untuk setiap job yang ada.

6. Mengurutkan $\left(\sum \mathrm{C}_{\mathrm{i}}\right)$ dengan aturan increasing order untuk diletakkan pada urutan setelah job yang sudah dipilih untuk urutan pertama sementara.

7. Setelah didapatkan urutan sementara, maka hitunglah Fmax-nya.

8. Mengulangi langkah 1-7 untuk setiap job yang ada yang akan ditempatkan sebagai urutan pertama dari urutan job sampai didapatkan $F_{\text {max }}$ (makespan) paling minimal.

9. Mengulangi langkah 1-8 untuk job yang akan ditempatkan pada posisi berikutnya yaitu posisi kedua, ketiga dan seterusnya setelah terpilih job untuk posisi pertama dengan nilai $F_{\max }$ minimum.

Adapun flowchart penjadwalan dengan algoritma heuristik pour seperti ditunjukkan pada Gambar 1.

Tabel 1. Data Order pada Bulan September 2013

\begin{tabular}{clcc}
\hline $\begin{array}{c}\text { Order } \\
\text { ke- }\end{array}$ & \multicolumn{1}{c}{ Jenis Order } & $\begin{array}{c}\text { Jumlah } \\
\text { Permintaan (unit) }\end{array}$ & Tanggal Masuk \\
\hline 1 & Kaos Arema & 250 & 2 September 2013 \\
2 & Kaos lengan panjang komunitas pecinta hewan & 140 & 9 September 2013 \\
3 & Kaos senam PNS Dinas Kehutanan Batu & 63 & 15 September 2013 \\
4 & Kaos v-neck komunitas vespa Malang & 126 & 20 September 2013 \\
5 & Kaos olahraga SMAN 7 Malang & 210 & 23 September 2013 \\
\hline
\end{tabular}




\section{Perbandingan Makespan}

Pada tahap ini dilakukan perbandingan makespan dari penjadwalan dengan algoritma heuristik Pour dan penjadwalan dengan metode awal perusahaan.

\section{HASIL DAN PEMBAHASAN}

Berdasarkan hasil wawancara dengan pemilik konveksi One Way terdapat 5 order yang diterima pada bulan September 2013 seperti ditunjukkan pada Tabel 1 .

Tahapan proses produksi pembuatan kaos adalah sebagai berikut :

1. Pembuatan pola dan pemotongan

Bahan baku yang berbentuk lembaran diberi pola sesuai order, setelah bentangan kain digambari pola, baru kemudian dipotong menggunakan gunting manual atau gunting listrik tergantung dari ketebalan kain.

2. Sablon

Proses penyablonan ini bertujuan untuk membuat artikel, warna serta logo pada baju dengan menggunakan mesin sablon.

3. Bordir

Proses bordir bertujuan untuk membuat tulisan dan logo yang timbul ke permukaan.

4. Penjahitan

Tujuan penjahitan membentuk sambungan jahitan dengan penampilan yang memenuhi standar jahitan.

5. Obras

Setelah semua baju dijahit menjadi satu, langkah selanjutnya adalah proses pengobrasan tepi jahitan dengan menggunakan mesin obras. Tujuan dari obras ini adalah untuk menjaga agar hasil jahitan tidak mudah terbuka.

6. Penyetrikaan

Pressing atau penyetrikaan memberikan pengaruh yang besar pada kenampakan proses produksi yang sudah jadi. Tujuan pressing adalah menghilangkan bekas-bekas lipatan yang tidak diinginkan, membuat lipatanlipatan yang diinginkan, membentuk pakaian sesuai dengan lekuk tubuh, dan membuat pakaian terlihat rapi.

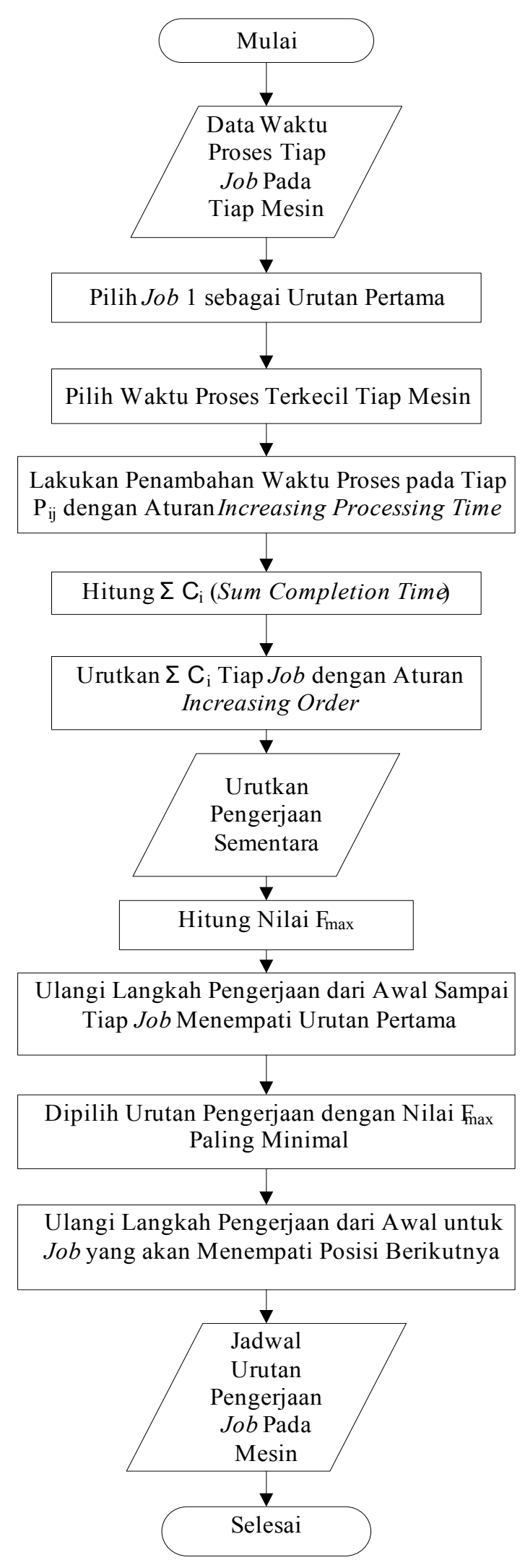

Sumber: Ginting, 2009

Gambar 1. Flow Chart Algoritma Heuristik Pour 
Tabel 2. Nama dan Jumlah Mesin di Setiap Stasiun Kerja

\begin{tabular}{cllccc}
\hline No & \multicolumn{1}{c}{ Stasiun Kerja } & \multicolumn{1}{c}{ Mesin } & Merk & Jumlah & Kapasitas produksi/mesin \\
\hline 1 & Pola dan Pemotongan & Mesin Potong (M1) & Mitsubishi & 6 & 3 \\
2 & Sablon & Mesin Sablon (M2) & - & 4 & 1 \\
3 & Bordir & Mesin Bordir (M3) & Mitsubishi & 8 & 1 \\
4 & Jahit & Mesin Jahit (M4) & Juki & 12 & 1 \\
5 & Obras & Mesin Obras (M5) & Yamata & 10 & 1 \\
6 & Penyetrikaan & Setrika Uap (M6) & - & 4 & 1 \\
\hline
\end{tabular}

Tabel 3. Data Waktu Standar Kaos di tiap Mesin

\begin{tabular}{lccccc}
\hline \multirow{2}{*}{ Mesin } & \multicolumn{5}{c}{ Waktu Standar (detik/unit) } \\
\cline { 2 - 6 } & Kaos Arema & Kaos Lengan Panjang & Kaos Senam & Kaos V-Neck & Kaos Olahraga \\
\hline Potong & 1398,55 & 1343,32 & 1386,53 & 1339,61 & 1362,62 \\
Sablon & 455,68 & 457,43 & 455,97 & 442,43 & 470,54 \\
Bordir & 457,30 & 365,88 & 1082,39 & 544,25 & 904,30 \\
Jahit & 180,69 & 184,67 & 214,78 & 182,45 & 198,41 \\
Obras & 90,29 & 92,27 & 105,28 & 90,15 & 105,99 \\
Seterika & 174,02 & 178,11 & 202,91 & 176,56 & 176,98 \\
\hline
\end{tabular}

\section{Packing}

Produkjadi dilipat hingga rapi dan dimasukkan pada plastik kemasan untuk melindungi dari debu dan kotoran.

Dari 7 tahapan tersebut, tahap kesatu sampai keenam menggunakan mesin dalam prosesnya. Tabel 2 menunjukkan nama dan jumlah mesin yang terdapat pada masing-masing stasiun kerja yang melaksanakan tahapan tersebut.

Waktu proses untuk membuat sebuah kaos pada tiap-tiap mesin diperoleh dengan melakukan pengukuran langsung menggunakan stopwatch. Selanjutnya dilakukan perhitungan waktu normal dan waktu standar dengan mempertimbangkan rating faktor dan kelonggaran. Dari hasil perhitungan dengan menggunakan persamaan 1 dan 2 diperoleh waktu standar masing-masing kaos pada tiap-tiap mesin dapat dilihat pada Tabel 3.

Tabel 3 menunjukkan waktu yang dibutuhkan setiap jenis kaos untuk diproses pada tiap mesin pada bulan September 2013. Sebagai contoh sebuah kaos Arema akan diproses di mesin potong, sablon,bordir, jahit, obras dan seterika masing-masing sebesar 1398,55; 455,68; 457,30; 180,69; 90,29 detik; dan 174,02 detik.
Konveksi One Way merupakan perusahaan yang bertipe make to order, sehingga produksi langsung dilakukan sejumlah permintaan yang ada pada tiap order. Oleh karena itu, input waktu untuk melakukan penjadwalan pengerjaan order pada Bulan September 2013 harus didasarkan dari total waktu proses. Total waktu proses yang dibutuhkan untuk menyelesaikan sebuah order dihitung dengan mempertimbangkan jumlah permintaan pada tiap order (Tabel 1), jumlah mesin (Tabel 2) dan waktu standar untuk membuat sebuah kaos (Tabel 3). Hasil perhitungan total waktu proses dengan menggunakan persamaan 3 ditunjukkan pada Tabel 4 .

Tabel 4. Total Waktu Proses Berdasarkan Masing-masing Order (dalam jam)

\begin{tabular}{ccccccc}
\hline \multirow{2}{*}{ Order } & \multicolumn{6}{c}{ Mesin } \\
\cline { 2 - 7 } & M1 & M2 & M3 & M4 & M5 & M6 \\
\hline 1 & 5,39 & 7,91 & 3,97 & 1,04 & 1,03 & 3,02 \\
2 & 2,90 & 4,45 & 1,78 & 0,59 & 0,36 & 1,73 \\
3 & 1,35 & 1,99 & 2,37 & 0,31 & 0,18 & 1,29 \\
4 & 2,60 & 3,87 & 2,38 & 0,53 & 0,31 & 1,54 \\
5 & 4,42 & 6,86 & 6,59 & 1,36 & 1,02 & 2,58 \\
\hline
\end{tabular}


Tabel 5. Perhitungan Makespan dengan Metode FCFS

\begin{tabular}{crrrccc}
\hline \multirow{2}{*}{ Order } & \multicolumn{7}{c}{ Mesin } \\
\cline { 2 - 7 } & \multicolumn{1}{c}{ M1 } & \multicolumn{1}{c}{ M2 } & \multicolumn{1}{c}{ M3 } & M4 & M5 & M6 \\
\hline 1 & $0 / 5,39$ & $5,39 / 13,30$ & $13,30 / 17,27$ & $17,27 / 18,31$ & $18,31 / 19,34$ & $19,34 / 22,36$ \\
2 & $5,39 / 8,29$ & $13,30 / 17,75$ & $17,75 / 19,53$ & $19,53 / 20,12$ & $20,12 / 20,48$ & $22,36 / 24,09$ \\
3 & $8,29 / 9,64$ & $17,75 / 19,74$ & $19,74 / 22,11$ & $22,11 / 22,42$ & $22,42 / 22,60$ & $24,09 / 25,38$ \\
4 & $9,64 / 12,24$ & $19,74 / 23,61$ & $23,61 / 25,99$ & $25,99 / 26,52$ & $26,52 / 26,83$ & $26,83 / 28,37$ \\
5 & $12,24 / 16,66$ & $23,61 / 30,47$ & $30,47 / 37,06$ & $37,06 / 38,42$ & $38,42 / 39,44$ & $39,44 / 42,02$ \\
\hline
\end{tabular}

Keterangan: $\mathrm{a} / \mathrm{b}=$ waktu mulai/waktu selesai

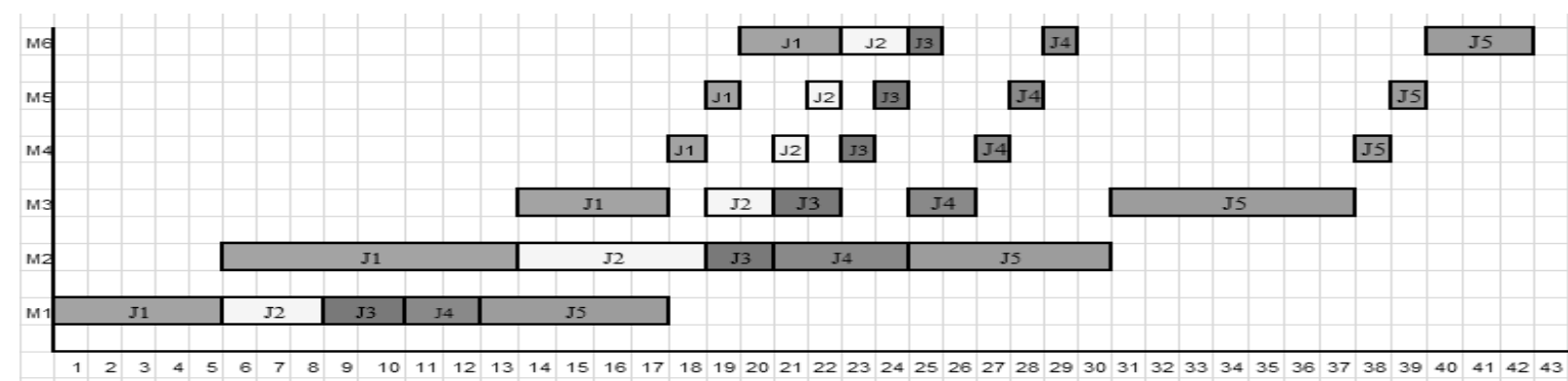

Gambar 2. Gantt Chart Penjadwalan pada Bulan September 2013 dengan Aturan FCFS

Waktu proses pada mesin sablon lebih lama dibandingkan mesin lainnya disebabkan keterbatasan jumlah mesin sablon yang dimiliki oleh perusahaan tersebut.

Penjadwalan dengan menggunakan aturan FCFS sesuai dengan prioritas order yang datang terlebih dahulu menghasilkan urutan pengerjaan order kaos pada Bulan September 2013: 1-2-3-45 dan nilai makespan $\left(F_{\max }\right)$ sebesar 42,02 jam. Hasil perhitungan waktu selesainya sebuah order di tiap mesin dan makespan dapat dilihat pada Tabel 5. Hasil penjadwalan dengan aturan FCFS dalam bentuk gantt chart ditunjukkan pada Gambar 2.

Penjadwalan order kaos menggunakan algoritma heuristik Pour pada konveksi One Way dilakukan dengan langkah-langkah sebagai berikut:

1. Memilih order 1 sebagai urutan pertama dalam urutan pengerjaan sehingga waktu proses order pada semua mesin dianggap nol.

2. Menempatkan order-order lain pada urutan berikutnya. Daftar pengurutan order 1 sebagai urutan pertama dapat dilihat pada Tabel 6 .
Tabel 6. Daftar Pengurutan Order 1 sebagai Urutan Pertama

\begin{tabular}{ccccccc}
\hline \multirow{2}{*}{ Order } & \multicolumn{7}{c}{ Mesin } \\
\cline { 2 - 7 } & M1 & M2 & M3 & M4 & M5 & M6 \\
\hline 1 & - & - & - & - & - & - \\
2 & 2,90 & 4,45 & 1,78 & 0,59 & 0,36 & 1,73 \\
3 & 1,35 & 1,99 & 2,37 & 0,31 & 0,18 & 1,29 \\
4 & 2,60 & 3,87 & 2,38 & 0,53 & 0,31 & 1,54 \\
5 & 4,42 & 6,86 & 6,59 & 1,36 & 1,02 & 2,58 \\
\hline
\end{tabular}

Tabel 7. Pemilihan Waktu Proses Terkecil pada Setiap Mesin

\begin{tabular}{lcccccc}
\hline \multirow{2}{*}{ Order } & \multicolumn{7}{c}{ Mesin } \\
\cline { 2 - 7 } & M1 & M2 & M3 & M4 & M5 & M6 \\
\hline 1 & - & - & - & - & - & - \\
2 & 2,90 & 4,45 & 1,78 & 0,59 & 0,36 & 1,73 \\
3 & 1,35 & 1,99 & 2,37 & 0,31 & 0,18 & 1,29 \\
4 & 2,60 & 3,87 & 2,38 & 0,53 & 0,31 & 1,54 \\
5 & 4,42 & 6,86 & 6,59 & 1,36 & 1,02 & 2,58 \\
\hline
\end{tabular}

3. Memilih waktu proses terkecil untuk masingmasing mesin yaitu: $\mathrm{M} 1=1,35 ; \mathrm{M} 2=1,99$; $\mathrm{M} 3=1,78 ; \mathrm{M} 4=0,31 ; \mathrm{M} 5=0,18 ; \mathrm{M} 6=1,29$. Waktu proses dapat dilihat pada Tabel 7. 
Tabel 8. Perhitungan Completion Time dengan Order 1 sebagai Urutan Pertama

\begin{tabular}{|c|c|c|c|c|c|c|c|}
\hline \multirow{2}{*}{ Order } & \multicolumn{6}{|c|}{ Mesin } & \multirow{2}{*}{$\mathbf{C i}$} \\
\hline & M1 & M2 & M3 & M4 & M5 & M6 & \\
\hline 1 & - & - & - & - & - &  & - \\
\hline 2 & 6,85 & 10,31 & 1,78 & 1,43 & 0,85 & 4,56 & 25,78 \\
\hline 3 & 1,35 & 1,99 & 4,15 & 0,31 & 0,18 & 1,29 & 9,27 \\
\hline 4 & 3,95 & 5,86 & 6,53 & 0,84 & 0,49 & 2,83 & 20,50 \\
\hline 5 & 11,27 & 17,17 & 13,12 & 2,79 & 1,87 & 7,14 & 53,36 \\
\hline
\end{tabular}

4. Melakukan penambahan waktu proses (completion time) pada setiap $\mathrm{t}_{\mathrm{i}, \mathrm{j}}$ dengan aturan increasing time yaitu dengan menambahkan waktu proses secara kumulatif dari terkecil sampai terbesar pada setiap $t_{i, j}$. Sebagai contoh urutan waktu proses di $M 1$ terkecil-terbesar adalah order 3, 4, 2, dan 5 sehingga waktu proses order 4 di M1 $=1,35+2,6=3,95 ;$ Order 2 di M1 $=3,95+2,90=6,85 ;$ Order 5 di M1 = $6,85+4,42=11,27$.

5. Menghitung sum completion time $(\Sigma C i)$ untuk setiap order yang ada seperti ditunjukkan pada Tabel 8.

6. Mengurutkan $\Sigma C i$ dengan aturan increasing time untuk diletakkan pada urutan setelah order 1 yang sudah dipilih sebagai urutan pertama. Dari hasil perhitungan diperoleh urutan sementara dengan order 1 sebagai urutan pertama yaitu: 1-3-4-2-5.

7. Menghitung nilai makespan dengan urutan pengerjaan order 1-3-4-2-5 seperti ditunjukkan pada tabel 9 dan diperoleh makespan sebesar 42,02 jam (sama dengan hasil penjadwalan dengan metode awal perusahaan).

Tabel 9. Perhitungan Makespan dengan Order 1 sebagai Urutan Pertama

\begin{tabular}{crrrrrc}
\hline \multirow{2}{*}{ Order } & \multicolumn{7}{c}{ Mesin } \\
\cline { 2 - 7 } & \multicolumn{1}{c}{ M1 } & \multicolumn{1}{c}{ M2 } & \multicolumn{1}{c}{ M3 } & \multicolumn{1}{c}{ M4 } & M5 & M6 \\
\hline 1 & $0 / 5,39$ & $5,39 / 13,30$ & $13,30 / 17,27$ & $17,27 / 18,31$ & $18,31 / 19,34$ & $19,34 / 22,36$ \\
2 & $5,39 / 8,29$ & $13,30 / 17,75$ & $17,75 / 19,53$ & $19,53 / 20,12$ & $20,12 / 20,48$ & $22,36 / 24,09$ \\
3 & $8,29 / 9,64$ & $17,75 / 19,74$ & $19,74 / 22,11$ & $22,11 / 22,42$ & $22,42 / 22,60$ & $24,09 / 25,38$ \\
4 & $9,64 / 12,24$ & $19,74 / 23,61$ & $23,61 / 25,99$ & $25,99 / 26,52$ & $26,52 / 26,83$ & $26,83 / 28,37$ \\
5 & $12,24 / 16,66$ & $23,61 / 30,47$ & $30,47 / 37,06$ & $37,06 / 38,42$ & $38,42 / 39,44$ & $39,44 / 42,02$ \\
\hline
\end{tabular}

Keterangan: $\mathrm{a} / \mathrm{b}=$ waktu mulai/waktu selesai

Tabel 10. Perhitungan Makespan dengan Order 2 sebagai Urutan Pertama

\begin{tabular}{crrrrrr}
\hline \multirow{2}{*}{ Order } & \multicolumn{7}{c}{ M1 } & \multicolumn{1}{c}{ M2 } & \multicolumn{1}{c}{ M3 } & \multicolumn{1}{c}{ M4 } & \multicolumn{1}{c}{ M5 } & \multicolumn{1}{c}{ M6 } \\
\cline { 2 - 7 } & $0,2,9$ & $2,9 / 7,35$ & $7,35 / 9,13$ & $9,13 / 9,72$ & $9,72 / 10,08$ & $10,08 / 11,81$ \\
2 & $2,9 / 4,25$ & $7,35 / 9,34$ & $9,34 / 11,71$ & $11,71 / 12,02$ & $12,02 / 12,2$ & $12,2 / 13,49$ \\
3 & $4,25 / 6,85$ & $9,34 / 13,21$ & $13,21 / 15,59$ & $15,59 / 16,12$ & $16,12 / 16,43$ & $16,43 / 17,97$ \\
4 & $6,85 / 11,27$ & $13,21 / 20,07$ & $20,07 / 26,66$ & $26,66 / 28,02$ & $28,02 / 29,04$ & $29,04 / 31,62$ \\
5 & $11,27 / 16,66$ & $20,07 / 27,98$ & $27,98 / 31,95$ & $31,95 / 32,99$ & $32,99 / 34,02$ & $34,02 / 37,04$ \\
\hline
\end{tabular}

Keterangan: $\mathrm{a} / \mathrm{b}=$ waktu mulai/waktu selesai

Tabel 11. Perhitungan Makespan dengan Order 3 sebagai Urutan Pertama

\begin{tabular}{crrrrrr}
\hline \multirow{2}{*}{ Order } & \multicolumn{7}{c}{ Mesin } \\
\cline { 2 - 7 } & \multicolumn{1}{c}{ M1 } & \multicolumn{1}{c}{ M2 } & \multicolumn{1}{c}{ M3 } & \multicolumn{1}{c}{ M4 } & \multicolumn{1}{c}{ M5 } & \multicolumn{1}{c}{ M6 } \\
\hline 3 & $0 / 1,35$ & $1,35 / 3,34$ & $3,34 / 5,71$ & $5,71 / 6,02$ & $6,02 / 6,2$ & $6,2 / 7,49$ \\
4 & $1,35 / 3,95$ & $3,95 / 7,82$ & $7,82 / 10,2$ & $10,2 / 10,73$ & $10,73 / 11,04$ & $11,04 / 12,58$ \\
2 & $3,95 / 6,85$ & $7,82 / 12,27$ & $12,27 / 14,05$ & $14,05 / 14,64$ & $14,64 / 15$ & $15 / 16,73$ \\
5 & $6,85 / 11,27$ & $12,27 / 19,13$ & $19,13 / 25,72$ & $25,72 / 27,08$ & $27,08 / 28,1$ & $28,1 / 30,68$ \\
1 & $11,27 / 16,66$ & $19,13 / 27,04$ & $27,04 / 31,01$ & $31,01 / 32,05$ & $32,05 / 33,08$ & $33,08 / 36,1$ \\
\hline
\end{tabular}

Keterangan: $\mathrm{a} / \mathrm{b}=$ waktu mulai/waktu selesai 
Tabel 12. Perhitungan Makespan dengan Order 4 sebagai Urutan Pertama

\begin{tabular}{crrrrrr}
\hline \multirow{2}{*}{ Order } & \multicolumn{7}{c}{ M1 } & \multicolumn{1}{c}{ M2 } & \multicolumn{1}{c}{ M3 } & \multicolumn{1}{c}{ M4 } & \multicolumn{1}{c}{ M5 } & \multicolumn{1}{c}{ M6 } \\
\cline { 2 - 7 } & \multicolumn{1}{c}{ M/2,6 } & $2,6 / 6,47$ & $6,47 / 8,85$ & $8,85 / 9,38$ & $9,38 / 9,69$ & $9,69 / 11,23$ \\
4 & $2,6 / 3,95$ & $6,47 / 8,46$ & $8,85 / 11,22$ & $11,22 / 11,53$ & $11,53 / 11,71$ & $11,71 / 13$ \\
3 & $3,95 / 6,85$ & $8,46 / 12,91$ & $12,91 / 14,69$ & $14,69 / 15,28$ & $15,28 / 15,64$ & $15,64 / 17,37$ \\
2 & $6,85 / 11,27$ & $12,91 / 19,77$ & $19,77 / 26,36$ & $26,36 / 27,72$ & $27,72 / 28,74$ & $28,74 / 31,32$ \\
5 & $11,27 / 16,66$ & $19,77 / 27,68$ & $27,68 / 31,65$ & $31,65 / 32,69$ & $32,69 / 33,72$ & $33,72 / 36,74$ \\
1
\end{tabular}

Keterangan: $\mathrm{a} / \mathrm{b}=$ waktu mulai/waktu selesai $\backslash$

Tabel 13. Perhitungan Makespan dengan Order 5 sebagai Urutan Pertama

\begin{tabular}{crrrrrc}
\hline \multirow{2}{*}{ Order } & \multicolumn{7}{c}{ M1 } & \multicolumn{1}{c}{ M2 } & \multicolumn{1}{c}{ M3 } & \multicolumn{1}{c}{ M4 } & \multicolumn{1}{c}{ M5 } & M6 \\
\cline { 2 - 7 } & \multicolumn{1}{c}{ Mesin } \\
\hline 5 & $0 / 4,42$ & $4,42 / 11,28$ & $11,28 / 17,87$ & $17,87 / 19,23$ & $19,23 / 20,25$ & $20,25 / 22,83$ \\
3 & $4,42 / 5,77$ & $11,28 / 13,27$ & $17,87 / 20,24$ & $20,24 / 20,55$ & $20,55 / 20,73$ & $22,83 / 24,12$ \\
4 & $5,77 / 8,37$ & $13,27 / 17,14$ & $20,24 / 22,62$ & $22,62 / 23,15$ & $23,15 / 23,46$ & $24,12 / 25,66$ \\
2 & $8,37 / 11,27$ & $17,14 / 21,59$ & $22,62 / 24,4$ & $24,4 / 24,99$ & $24,99 / 25,35$ & $25,66 / 27,39$ \\
1 & $11,27 / 16,66$ & $21,59 / 29,5$ & $29,5 / 33,47$ & $33,47 / 34,51$ & $34,51 / 35,54$ & $35,54 / 38,56$ \\
\hline
\end{tabular}

Keterangan: $\mathrm{a} / \mathrm{b}=$ waktu mulai/waktu selesai

8. Mengulangi langkah 1-7 untuk setiap order yang ada yang akan ditempatkan sebagai urutan pertama sampai didapatkan nilai makespan paling minimal. Setelah order 1 dipilih sebagai urutan pertama maka berikutnya order 2 sebagai urutan pertama, sehingga diperoleh urutan order sementara 2-3-4-5-1 dengan makespan 37,04 jam. Hasil perhitungan selengkapnya dapat dilihat pada Tabel 10.

Nilai makespan untuk order 3 sebagai urutan pertama dengan urutan order sementara 3-4-2-5-1 adalah 36,1 jam ditunjukkan pada Tabel 11. Nilai makespan untuk order 4 sebagai urutan pertama dengan urutan order sementara 4-3-2-5-1 adalah 36,74 jam ditunjukkan pada Tabel 12. Nilai makespan untuk order 5 sebagai urutan pertama dengan urutan order sementara 5-3-4-2-1 adalah 38,56 jam ditunjukkan pada Tabel 13. Berdasarkan perhitungan pada langkah 8 diperoleh order 3 sebagai urutan pertama dengan urutan order sementara 3-4-2-5-1 memberikan makespan terkecil sebesar $36,1 \mathrm{jam}$.

9. Mengulangi langkah 1-8 untuk order yang akan menempati posisi berikutnya yaitu pada posisi kedua, ketiga, dan seterusnya setelah order 3 sebagai urutan pertama. Rekapitulasi hasil perhitungan pada langkah 9 dapat dilihat pada Tabel 14 .

Tabel 14 menunjukkan urutan order sementara 3-4-5-1-2 terpilih karena memberikan makespan yang paling minimum sebesar 33,93 jam dan diperoleh urutan pengerjaan order pada bulan September 2013 dengan metode heuristik Pour adalah 3-4-5-1-2. Tabel 15 dan Gantt Chart

Tabel 14. Rekapitulasi Iterasi Heuristik Pour pada Langkah 9

\begin{tabular}{|c|c|c|c|c|c|c|}
\hline \multirow[t]{2}{*}{ Iterasi } & \multicolumn{4}{|c|}{$\begin{array}{c}\text { Order pada } \\
\text { urutan } \\
\text { sementara ke- }\end{array}$} & \multirow[t]{2}{*}{$\begin{array}{c}\text { Urutan } \\
\text { Order }\end{array}$} & \multirow[t]{2}{*}{ Makespan } \\
\hline & 1 & 2 & 3 & 45 & & \\
\hline \multirow[t]{4}{*}{1} & 3 & 1 & & & $3-1-4-2-5$ & 41,38 \\
\hline & 3 & 2 & & & $3-2-4-5-1$ & 36,4 \\
\hline & 3 & 4 & & & $3-4-2-5-1$ & 36,1 \\
\hline & 3 & 5 & & & $3-5-4-2-1$ & 37,92 \\
\hline \multirow[t]{3}{*}{2} & 3 & 4 & 1 & & $3-4-1-2-5$ & 40,11 \\
\hline & 3 & 4 & 2 & & $3-4-2-5-1$ & 36,1 \\
\hline & 3 & 4 & 5 & & $3-4-5-1-2$ & 33,93 \\
\hline 3 & 3 & 4 & 2 & 1 & $3-4-2-1-5$ & 38,59 \\
\hline
\end{tabular}


Tabel 15. Perhitungan Makespan dengan Urutan Pengerjaan Order Terpilih

\begin{tabular}{crrrrrr}
\hline \multirow{2}{*}{ Order } & \multicolumn{7}{c}{ Mesin } \\
\cline { 2 - 7 } & \multicolumn{1}{c}{ M1 } & \multicolumn{1}{c}{ M2 } & \multicolumn{1}{c}{ M3 } & \multicolumn{1}{c}{ M4 } & \multicolumn{1}{c}{ M5 } & \multicolumn{1}{c}{ M6 } \\
\hline 3 & $0 / 1,35$ & $1,35 / 3,34$ & $3,34 / 5,71$ & $5,71 / 6,02$ & $6,02 / 6,2$ & $6,2 / 7,49$ \\
4 & $1,35 / 3,95$ & $3,95 / 7,82$ & $7,82 / 10,2$ & $10,2 / 10,73$ & $10,73 / 11,04$ & $11,04 / 12,58$ \\
5 & $3,95 / 8,37$ & $8,37 / 15,23$ & $15,23 / 21,82$ & $21,82 / 23,18$ & $23,18 / 24,2$ & $24,2 / 26,78$ \\
1 & $8,37 / 13,76$ & $15,23 / 23,14$ & $23,14 / 27,11$ & $27,11 / 28,15$ & $28,15 / 29,18$ & $29,18 / 32,2$ \\
2 & $13,76 / 16,66$ & $23,14 / 27,59$ & $27,59 / 29,37$ & $29,37 / 29,96$ & $29,96 / 30,32$ & $30,32 / 33,93$ \\
\hline
\end{tabular}

Keterangan: $a / b=$ waktu mulai/waktu selesai

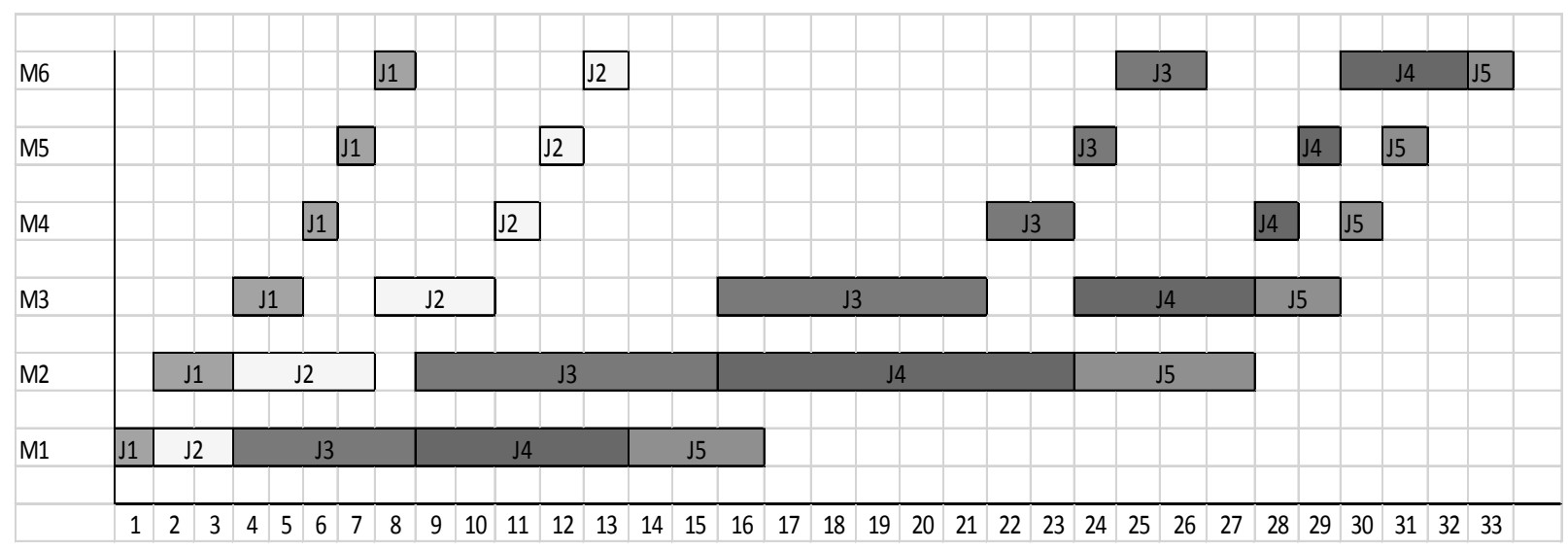

Gambar 3. Gantt Chart Penjadwalan Bulan September 2013 dengan Metode Heuristik Pour

pada Gambar 3 menunjukkan perhitungan waktu mulai dan selesainya tiap order pada tiap mesin serta makespan dari hasil penjadwalan dengan algoritma heuristik Pour. Setelah diperoleh penjadwalan dengan metode awal perusahaan dan metode usulan maka langkah selanjutnya adalah melakukan perbandingan untuk melihat apakah algoritma heuristik Pour mampu meminimalkan makespan.

Tabel 16 menunjukkan penjadwalan dengan metode usulan memiliki waktu penyelesaian lebih cepat daripada penjadwalan awal perusahaan yaitu sebesar 8,09 jam atau sebesar 19,25\%.

Tabel 16. Perbandingan Hasil Penjadwalan Awal dan Penjadwalan Usulan

\begin{tabular}{lcc}
\hline & $\begin{array}{c}\text { Penjadwalan } \\
\text { Awal }\end{array}$ & $\begin{array}{c}\text { Penjadwalan } \\
\text { Usulan }\end{array}$ \\
\hline Urutan & $1-2-3-4-5$ & $3-4-5-1-2$ \\
Makespan & 42,02 jam & 33,93 jam \\
\hline
\end{tabular}

Algoritma heuristik Pour terbukti memberikan efisiensi waktu karena makespan yang lebih kecil. Hal ini sejalan dengan penelitian yang telah dilakukan oleh Afina dkk. (2012) dalam melakukan penjadwalan produksi diperoleh sehingga order dapat diselesaikan tepat pada waktunya.

\section{SIMPULAN}

Metode heuristik Pour dapat digunakan sebagai alternatif metode dalam melakukan penjadwalan pengerjaan order di konveksi One Way. Penjadwalan dengan menggunakan metode heuristik Pour menghasilkan makespan lebih cepat sebesar 8,09 jam dari metode FCFS pada Bulan September 2013. Dalam aplikasi algoritma heuristik Pour maka perlu adanya dokumentasi mengenai data-data produksi atau waktu dalam menyelesaikan pekerjaan pada setiap elemen kerja agar dapat memudahkan untuk pengembangan produksi selanjutnya. 


\section{DAFTAR PUSTAKA}

Afina, I.N., Anugraha, R.A., dan Suryadhini, P.P., 2012. Penjadwalan Produksi Flowshop untuk Meminimasi Makespan dengan Analisis Perbandingan Metode Heuristic Pour dan Campbell, Dudek, and Smith (CDS) pada Lantai Produksi Profil Alumunium di PT. Lndosaluyu Primajaya Cimahi, Prosiding Industrial Engineering Conference on Telecomunication, Universitas Riau.

Baker, K.R., and Trietsch D., 2009. Principles of Sequencing and Scheduling, New York: John Wiley \& Sons.

Ginting, R., 2009. Penjadwalan Mesin, Yogyakarta: Graha Ilmu.
Pour, H.D., 2001. A New Heuristic for n-Job m-Machine Flowshop Problem, Production Planning and Control, 12 (7), 648-653.

Siregar, A.H.O., 2009. Analisis Perbandingan Kinerja antara Algoritma Heuristic Pour dan Algoritma Nawaz, Enscore dan Ham (NEH) dalam menyelesaikan Penjadwalan Flowshop pada PT Cakra Compact Aluminium Industries Medan, Tugas Akhir, Teknik Industri, Universitas Sumatera Utara.

Tessa, V. S. dan Palit, H. C., 2004. Studi Perbandingan Performance Heuristik Pour terhadap Mixed Integer Programming dalam Menyelesaikan Penjadwalan Flowshop, Jurnal Teknik Industri, 6 (1), 79-85. 